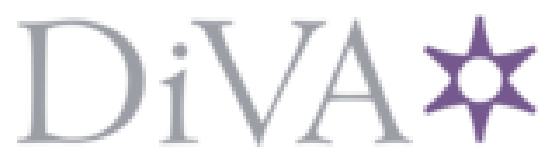

http://www.diva-portal.org

This is the published version of a paper published in African Journal of Business Management.

Citation for the original published paper (version of record):

Vaaland, T., Soneye, A., Owusu, R. (2012)

Local content and struggling suppliers: a network analysis of Nigerian oil and gas industry.

African Journal of Business Management, 6(15): 5399-5413

http://dx.doi.org/10.5897/AJBM1 1.2538

Access to the published version may require subscription.

N.B. When citing this work, cite the original published paper.

Permanent link to this version:

http://urn.kb.se/resolve?urn=urn:nbn:se:lnu:diva-30792 


\title{
Local content and struggling suppliers: A network analysis of Nigerian oil and gas industry
}

\author{
Terje I. Vaaland ${ }^{1 *}$, Alabi S. O. Soneye ${ }^{2}$ and Richard A. Owusu ${ }^{3}$ \\ ${ }^{1}$ University of Stavanger, UiS Business School, Ullandhaug, NO-4035 Stavanger, Norway. \\ 'University of Lagos, Nigeria. \\ ${ }^{3}$ University of Vaasa, Finland. \\ Accepted 19 December, 2011
}

\begin{abstract}
The study investigates how local content can be enhanced in the oil and gas industry in a developing country like Nigeria. The empirical base was 18 in-depth interviews of professionals directly or indirectly related to the Nigerian oil and gas industry. The interviews revealed barriers for indigenous companies in accessing the industry. These were related to three major capabilities; capital, competence and delivery possibilities. It is suggested that the barriers can be solved by recognition of the interdependencies between actors associated with these capabilities. The actors include in addition to the foreign companies and the indigenous companies, educational institutions, legal system, educational and $R$ and $D$ institutions, financial institutions, industrial regulators and providers of infrastructure. The paper suggest framework for understanding the oil industrial network of Nigeria. The findings have implications for local content in all developing nations having a significant natural resource extraction industry.
\end{abstract}

Key words: Nigeria, oil industry, local content, industrial network, business relationships, sourcing.

\section{INTRODUCTION}

Despite the richness of natural oil resources, Nigeria is ranked the 20th poorest country in the world. Much of the country's poverty and underdevelopment can be contributed to the misguidance in governance, mismanagement of resources, various political issues and lack of infrastructures (Adams et al., 2008). The country's level of GDP per capita was, a few years back, below the level at independence 40 years ago, and income inequality was widening (Boscheck, 2007). The oil and gas industry is, however, a major contributor to the Nigerian economy. It accounts for about $90 \%$ of the federal government's annual revenue (Nwosu et al., 2006). The industry is, however, dominated by foreign interests and major activities like exploration, drilling, production, well intervention and service provision remain primarily controlled and managed by foreign

*Corresponding author. E-mail: terje.vaaland@uis.no. Tel: +47 90981256. Fax: +4751833750 , multi-national companies, and only minor contracts have been awarded to local contractors (ibid). In order to increase local industry's participation in the oil and gas industry of Nigeria, local content requirements (LCR) have been made legally mandatory, which implies that foreign companies involved in exploring and exploiting the resources in Nigeria, are forced to include indigenous companies. With a few exceptions, the foreign companies are large multinational enterprises (MNEs). For example, $95 \%$ of Nigeria's oil and gas production is generated by only five companies; Shell, Exxon, Chevron, Total and Agip (Frynas and Paulo, 2007). Historically, the involvement by foreign companies in developing countries has been motivated by a desire to exploit natural resources and abundant labor pools (Hansen et al., 2009). Now they are faced with new challenges, which can be related to three basic questions: Firstly, do indigenous companies have the sufficient competence, skills and equipment to deliver? Secondly, if the local industrial base is insufficient, how can the resource base be enhanced? And finally, who are the actors necessary 
to provide and support changes in the local industrial base?

These questions are not new. One line of previous studies investigate the economic aspects of local content by focusing on diffusion of technology transfer, vertical integration and division of work (Kwon and Chun, 2009; Tallman and Phene, 2007; Aharonson et al., 2007), effects of enhanced local content on welfare (Veloso, 2006; Takechi and Kiyono, 2003), local content effects on Foreign Direct Investments (Lahiri and Ono, 1998; Qui and Tao, 2001; Jensen and Tarr, 2008), and experience with local content requirements from the perspective of industrialized countries (Pursell, 2001). Others scrutinize the vertical (backward) linkages between foreign multinationals and local suppliers. These vertical linkages go beyond pecuniary exchange and bring in technical, but also informational, financial, organizational and managerial externalities (Ivarsson and Alvstam, 2009; Giroud, 2007). A third line of research focus on the interrelatedness between the various actors and their capabilities, and argue for the importance of understanding local content in an integrative way by including several capabilities. One example is when Silvestre and Dalcol (2009) describe the interrelatedness between actors and support organizations involved in the Brazilian oil and gas industry. These included regulatory agency affiliated to the ministry of mines and energy, industry organizations and commercial associations, service providers of credit, technical and management training, interactions facilitators, project analysis etc., municipal and state's supporting organizations and universities/research institutions and the national oil company Petrobras (ibid). This view in line with Giroud (2007) which claims that the interrelatedness between factors related to the MNE itself, the growth of the industrial base, and level of local or national policies. This paper follows the line represented by Silvestre and Dalcol (2009) and Giroud (2007), and tries to reveal the interdependencies between the various industrial actors and public institutions in Nigeria. We argue that this interaction between several actors is crucial for achieving local participation in the oil and gas industry, in which foreign MNEs and foreign suppliers dominate. It considers a business network including indigenous service and manufacturing companies, governmental policy makers, financial institutions, universities and research institutions amongst others. By addressing this issue, we contribute to fill a knowledge gap between current studies of local content and the realities facing a developing country with richness of oil and gas. Our theoretical framework is based on the industrial network approach in which relationships between the actors are embedded in a larger network. In other words, it is assumed that the relationship between the buyer (that is, the MNE) and the seller (that is, the indigenous company) are affected by other relationships in the network, for example, the relationship between research and educational institutions and indigenous companies.

The aim of this paper can be summarized into two questions:

1. Which actors are relevant for increasing local content in the Nigerian oil and gas industry?

2. How are the capabilities provided by the actors interrelated, and why?

The paper is based on in-depth interviews with representatives from the Nigerian oil and gas industry and supporting actors in what we refer to as the Nigerian oil industrial network.

This paper is organized into five sections. The first is a review of the concept of business relationships and industrial networks. It is followed by the methodology, and the findings. The discussion of the implications is supported by a proposed conceptual model for understanding 'local content' in the developing country context, before concluding the paper.

\section{THE CONCEPT OF BUSINESS RELATIONSHIPS AND NETWORKS}

The core idea of industrial network approach is that the firm is understood and explained in terms of its relationships and how these relationships are embedded in a larger network of actors (Ford et al., 2006). Networks constitute forms of voluntary co-operation such as information sharing, mutual learning and exchange between cooperating firms and social control. Firms obtain relevant information by means of their involvement in different networks (Johannisson and Ramirez-Pastillas, 2002). In order to understand the importance of network interaction among industrial actors, Ford et al. (2003) presented and challenged two common myths on how a company functions and is perceived. The first is the myth of completeness and the second the myth of independence. The first is based on the traditional ideas of strategy and emphasizes that a company's own resources, skills and internal competencies and shortcomings allow it to operate on the basis of its own resources and abilities. The industrial network approach proposes that the company lacks sufficient resources to satisfy the requirements of customers. The company is therefore dependent on the skills, resources, actions and intentions of suppliers, distributors, customers and even competitors to meet market requirements. Similarly, no company can exploit its own resources except in relationships with other actors and their sets of resources.

The myth of independence is based on the traditional ideas of strategy, assuming that a company is able to act independently, carrying out its own analysis of the environment in which it operates, developing and implementing its own strategy based on its own 
resources and taking into account its own competences and shortcomings. According to the industrial network approach, however, no company can understand its environment without considering the effects of relationships with other companies and networking actors. The assumption of the company as incomplete and interdependent can be analyzed in three dimensions which combine as driving force for the development of business relationships and thus the outcome of the network. They include actor bonds, resource ties and activity links (Håkansson and Snehota, 1995). The interplay of the three is briefly described subsequently.

Actor bonds are social, legal and economic ties that bind the network actors together and influence their mutual perception of each other. They include trust, commitment, investments and social relationships. The bonds have great importance in problem-solving and reassurance between the companies. They influence how two companies perceive each other and form their identities in relation to each other (Håkansson and Snehota, 1995). They determine the patterns of resource allocations and the activities between companies to a large extent (Ford et al., 2006). The challenge is to develop actor bonds which enable a relationship to prosper. Many scholars characterize mutual commitment and trust as the basic elements of the actor bonds described above. Commitment is the desire to maintain a relationship. It is indicated by on-going investment" activities which are expected to maintain the relationship (Blois, 1997). Anderson and Weiz (1989) define commitment to a relationship as a desire to develop a stable relationship, a willingness to make short-term sacrifices that could maintain the relationship and a confidence in the stability of the relationship. Trust is an acceptance of vulnerability to another's possible, but not expected, ill will (Kalafatis and Miller, 1997) and is considered as the initiator and guiding mechanism for partner-specific adaptation and processes (Blau, 1964). The two key components encourage partners (i) to make investments into the relationship; (ii) to resist taking advantage of alternatives which provide short-term benefits, and (iii) not to behave opportunistically with regard to the relationship (Blois, 1997).

A resource is a relative concept, rather than an element in itself (Håkansson and Snehota, 1995). It is heterogeneous and assumed as interdependent with other resources. Resource ties connect various resource elements of focal companies such as organizational, technological, material, knowledge resources and other intangibles (ibid). It is from the successive combination and recombination of resources that innovative solutions spring up while the outcomes may lead to improved resources utilization and the development of new resources within the technical, physical or operational areas. Over time, repeated transactions between focal parties lead to activity links in many aspects of operations, design and production logistics, physical flow of deliveries and other related procedures, routines and systems (Ford et al., 2003). Activity links co-ordinate different activities of focal companies in the relationship and create efficient activity structures (Håkansson and Snehota, 1995).

\section{METHODOLOGY}

Based on previous data collection experience in Nigeria and the character of our investigation, the topics were considered sensitive among the informants. According to Tourangeau et al. (2000), a perception of sensitivity include the treat of disclosure, invasion of privacy and a risk of disclosure of answers to a third party, which easily lead to low response rate or reluctance to be interviewed, or more importantly, dishonest and socially desirable responding (Zerbe and Paulhus, 1987). It was therefore decided to drop questionnaires and adopt open ended face-to-face interviews. This methodology give an advantage in the way that mutual trust can be built during the interview process, and thus lead to more openness and possibly more valid answers than an impersonal survey. The process included interviews with sampled informants in the Nigerian oil and gas industry.

The 14 organizations were identified and selected from the 48 recommended by regulatory agencies, the purchase and supply units of priority companies and unions/associations from (i) the database of the Nigerian Local Content Board and (ii) the directories of 6 major Nigeria business advertisement websites viz.: www.1stnigeriadirectory.com, www. afrowall.com, www. nairalandforu m.com,www.nigeriagallery.com, www.nigforumsocialnet.com and www.sourcecheck.com. The choice was based on the information accessible on the companies, their operational interests and competences between July and September 2010. Their mandates cover oil and gas exploration, service providers, industrial suppliers, consultancy, university, finance, union and governmental bodies. The main informants (18 in all) included presidents, managers/directors and heads of marketing, legal and local content departments as well as principal partners, secretaries and $R$ and $D$ deans, and heads of academic units.

A structured open ended question interview guide (Appendix 1) was adopted. It covers the aspects of specific business ideas and philosophies of respective companies as a player in the industry, nature of competitiveness, the driving and counteracting forces and collaboration/merger with counterpart indigenous and foreign companies. Further emphases are on their competencies, operations, facilities and managerial capabilities, capacity building, technological sourcing and transfer, research and training locally and overseas as well as relationship with Nigerian universities/R and $D$ institutions, corporate social responsibilities and local content policies. The exercise was accomplished by two researchers between 4th and 14th October, 2010. Eleven of the organizations were based in Lagos and three in Abuja, with their field operational offices in the oil producing Niger Delta area. The interview sessions lasted between $45 \mathrm{~min}$ and $2 \mathrm{~h}$. After each interview, notes were compared for clarifications and filed.

\section{FINDINGS AND ANALYSIS}

The findings are organized into six relationships which were identified in our data collection process. These relationships were commented by a variety of actors, although with different perceptions of importance. In the following the most important aspects in the relationships will be presented. 


\section{Relationship 1: Indigenous suppliers and finance institutions}

According to the majority of informants, the relationship between the indigenous company and finance institutions suffers from lack of funding, even for companies claiming to have competence and skills through current business relationships with foreign oil companies. This frustration can be illustrated by the following three indigenous service provider informants:

"I have the market access, a PhD in the field and 20 years of business experience, but cannot get finance from banks to fund equipment for expansion. For USD 20 million, I could buy the equipment, and create high-tech jobs for 25 people. I would not get even USD 1 million from Nigerian banks, even with an effective annual interest rate of $25 \%$ ". (A service provider company informant).

"If we had unlimited access to finance, we could increase our number of employees from 200 today to around 2000 since we have the customers and the products. The problem is to get bank guarantees, which limits our ability to access capital from abroad". (An indigenous service provider company informant).

"Access to funding for an investment of USD 40 to 50 million could increase our revenue from USD 8 to 300 million, and increase staff from 50 to between 600 and 1000. There would be cumulative effects on the number of our independent distributors for our products". (An indigenous service provider company informant).

The existing relationship between the indigenous suppliers and finance institutions is further confirmed by a foreign oil company informant who stated that:

"....the interest rates in the country are effectively between 23 to $25 \%$ p.a., whereas foreign companies get funding form international banks for 6 to $10 \%$ p.a. Loans are short term and normally limited to 6 months. This is a major constraint to realization of profitable projects". (A foreign exploration and production company informant).

Both financial institutions and companies expressed a critical shortage of financial resources available for developing indigenous industry. Albeit, differences in perceptions of whom to blame for capital shortages, lack of trust between the lender and borrower seems to be the major constraint for accessing capital.

Firstly, the bank informant claims that Nigerian banks have a low trust in the ability and willingness of indigenous companies to pay back while all the informants claimed that the foreign investors are far more willing and able to pay back loans. Yet, the foreign companies and other actors such as labour unions claim that the lack of trust and thus lack of funding are often self-imposed by lawless local companies that breach agreements and loan conditions.

Secondly, distrust of potential local borrowers in the industry is worsened by weak legal and court system in the country. Both the foreign and indigenous companies interviewed claim that the court system cannot be trusted, cases could be challenged for a very long time and enforcement of judgment is slow. The payback behaviour and legal system lead to strict, and perhaps unrealistic, requirements for collaterals and security for loans.

Thirdly, Nigerian banks suffer low reputation in the international financial markets. This reduces their access to international money markets and ability to build interbank consortiums with their foreign counterparts.

Finally, several of the informants claim that the Nigerian banking institutions suffer from eagerness to remain independent just like the indigenous companies. This prevents mergers and consolidation into larger and more powerful institutions as well as increased professionalism.

The consequence is that the banks remain small and weak as lending institutions. In sum, lack of a functional banking system is considered as the major constraint to developing and realizing business opportunities.

\section{Relationship 2: The industry and Universities/R and D Institutions.}

Both the industry and the University/R and $\mathrm{D}$ institution informants express difficulties in building interorganizational relationships albeit both parties acknowledge the importance of exchanging research, educational, managerial and technological skills to enhance competitiveness. The interfaces between the graduate students, researchers and local business community are weak, resulting in weak exchange of knowledge and feedback loops. Some of these can be related to either actor bonds and/or resource ties in that the actor bonds suffer from lack of trust. This is manifested through reluctance from the industry to reveal information which may be published and/or used against the interest of some companies. The following statement from a university professor is one illustration:

'Some foreign companies are not ready to support any studies on enhancing competitiveness by local peers, either by product or process assessments or through questionnaires, interviews, fieldworks or any other means of data collection. Many indigenous companies are not conversant of the need for such while many of the foreign companies are afraid of the effects on their operational interests as they are not sure of what would happen if the results are contrary to required 'best practice' in the industry". (A Nigerian university professor).

However, both parties acknowledge the need for building 
local competence, knowledge transfer and exchange through direct interaction and joint ventures with foreign suppliers. Competencies of particular interest include project and contract management, contractual skills, quality assurance, safety performance, legal requirements and technological development. One indigenous manager with long international experience assumed that the weak resource ties between the Universities and industry affect technological development and transfer, noting that:

'...technology is something which is acquired through joint ventures with foreign companies, and not an issue that Nigerian firms invest in and not an issue for development within Nigerian $R$ and $D$ institutions and universities'. (An indigenous service provider company informant).

This is further explained by another indigenous informant who argued that in general, indigenous companies are small, lack capital for R and D, and lack awareness on the potentials for accessing new knowledge beyond own experience.

In some countries with mature oil industry such as Norway, the industry has throughout the last 40 years donated used, but still modern, equipment and tools to universities and research institutions for training and educational purposes when modernizing facilities. Such hardly exist in the Nigerian context. The university informants claim that there are some efforts in strengthening these relationships. These include activities such as training scholarships, short term industrial attachment experiences on a few Bachelors programs; and that in recent times, some departments are hiring retired but still active CEO's as Adjunct Professors to mitigate the current brain drain in the academics and also meet the staff requirements of new private universities. This may improve their curricular and balance the relationship between stakeholders.

\section{Relationship 3: Indigenous suppliers and foreign buyer companies}

The overall competitiveness of indigenous companies is perceived as very weak by both the buyer and seller sides. The reasons given by the respondents are described as follows:

\section{Corruption}

All informants confirm there is a serious corruption problem in Nigeria, which in turn has a negative effect on the reputation of indigenous suppliers. It can have many forms. One is explained by an indigenous informant as follows:
"Of the contract value of 100, 50 are shared between two individuals, one from seller and one from buyer. The remaining 50 is payment for the delivery expected to be worth 100 . As a result the intended delivery is diluted to 50 , a secrecy shared between the individuals in buyer and seller firms". (An indigenous service provider company informant).

Another form is related to manipulation of the bidding process. The informants indicated that there is always manipulation at bid advertisement and also at contract award. Both the bidding indigenous companies as well as the contract-awarding foreign companies are involved. Both the givers and takers hate it but cannot prevent it because of the fear of losing businesses. Corruption in the business relationships also has an effect on the way indigenous companies trust each other, and ability to develop larger and more competitive business units.

\section{Lack of competence and skills}

There are significant knowledge gaps between the indigenous companies, foreign competitive suppliers and foreign oil companies as buyers. The gaps are in two major areas. The first is related to lack of skills and technical competencies in areas such as welding, engineering, general technological competencies, as well as management competencies such as project management, contractual skills, quality assurance, and legal requirements. The gaps lead to lack of necessary certification, loss at prequalification for contract awards and thus inaccessibility to bidders' lists. The second is related to in-competencies based on fundamental attitudes. One of these is the perception of quality and how this is manifested in terms of preventive and operational maintenance. Foreign companies and some of the indigenous companies informed us of fundamental lack of quality understanding among indigenous companies, their limited compliance with international quality standards and poor preventive and operational maintenance attitudes, all leading to poor maintenance of facilities. An indigenous informant with long international experience concluded that "...lack of a quality and maintenance culture makes local content ambitions challenging".

\section{Structures of contracts}

The poor relationships manifest in the way contract packages are designed by buyer foreign companies. One indigenous informant claimed that the size and complexity of contracts are difficult to bid for by relatively small indigenous companies. Other informants suggested that contracts should either be broken down into smaller packages, or indigenous companies should merge into larger companies to be competitive. 


\section{Governmental support}

All the informants commend the Local Content Act (2010) as a good starting point for enhancing the competitiveness of indigenous companies. The indigenous companies noted that the concessions for indigenous companies by the Act will influence foreign companies' ability to substitute foreign suppliers with Nigerian supplier and contactors. The foreign companies also argued that the Act is necessary for initiating and developing 'supplier development programs' with the purpose of qualifying more local suppliers. However, they are afraid that it would be unrealistic without a stronger governmental role in developing and investing in basic infrastructures. A foreign company informant claimed that:

"The infrastructure is not missing, it is rather dysfunctional". A union executive noted that "poor electricity, for example, has forced some companies to fold up or move to neighbouring countries (especially Ghana). The latter, export their raw materials from Nigeria, produce in Ghana and import the finished products back to Nigeria'. (An indigenous service provider company informant).

All the indigenous companies noted the importance of significant governmental contribution in enforcing and developing pipelines, waterways and complimentary transport facilities including roads and rail system. The views are captured in the statement by an indigenous supplier: "The poor infrastructure is related to such as harbour capacity, cranes, docking and water depth. Only minor work is possible without significant infrastructure investments". Another supplier argued that that poor infrastructure escalates production and logistics costs locally and reduce competitive advantage. "Whereas foreign indirect unit cost is $1 / 3$, the Nigerian cost is $3 / 4$ ". The challenge to the foreign companies can be summarized in the question by an informant: 'How much cost burden is the foreign company willing to take in order to comply with the Act and continue investing in Nigeria?'

\section{Relationship 4: The legal system and the industrial network.}

When trust in business relationships fails and relations are put under pressure, a legal system is necessary to provide justice. Legal institutions lacking trust will easily reduce the willingness to develop commitment in business relationships. All groups of informants concur that the court system in Nigeria can hardly be trusted. They are of strong perception that bribery is apparent in the legal system and in the law enforcement agencies. Even though laws exist, they are often porous, disrespected and not enforced, and the legal system gives room for conflicts and manipulation sometimes as cases won in courts could be appealed frivolously over a very long time and be difficult to interpret or execute. The consequence is stated by one local company; "justice delayed is justice denied". The deficits in the legal system and law enforcement lead to many cases being settled out of courts after much frustration. Business partners therefore depend on relational trusts. This is not sufficient for serious investments, may lead to disinvestment and reduce intended effects on local content.

\section{Relationship 5: Regulatory bodies and foreign companies/R and D/Universities}

The informants identified three main roles of government in sustaining a competitive local supplier industry. The first is to improve the knowledge transfer from the foreign companies to the universities and/or $R$ and $D$ institutions by law or incentives, and thereby improve the knowledge base on which the indigenous companies are dependent. The second is to sustain knowledge transfer from the foreign companies to indigenous companies directly, for example through the Local Content Act. The last is to create effective political and managerial processes that would facilitate industrial growth.

\section{Knowledge transfer}

An informant from a large foreign company expressed the crucial need for technology transfer from foreign companies to local supplier market. This view has led to investments in supplier development programs. Unfortunately, there are no incentives or involvement from the governmental bodies to sustain the program. An indigenous company noted that the missing link between universities and local business is not recognized by government, and that the role of the government for knowledge generation and diffusion is very limited.

\section{Political and managerial processes}

Some governmental initiatives are considered highly supportive in developing indigenous companies. They include introduction of the Local Content Act, the establishment of a supplier developing fund, the Local Content Monitoring Board, reduction in corruption through the country's economic and financial crimes commission (EFCC) and improved transparency in the bidding process through registration and creation of database on competent indigenous supplier-bidder companies in different areas and restricting bidders to the database.

On the other hand, the government is accused of failure to design sustainable duty regimes that favour local production over importation. One indigenous 
company argued that there is zero duty on import to tax free zones but heavy duties on materials necessary for local production such as steel. The problem is summarized by a foreign oil company as follows: "If you import a completed pressure valve, the duty is $15 \%$, but if you buy the steel plates for local production the duty is $35 \%$ ". Failed infrastructure in terms of roads, electricity, harbours, facilities and pipelines are noted commonly amongst a long list of infrastructural challenges to a competitive indigenous suppler industry.

The ways political and governmental decisions are made without recourse to pertinent stakeholders is of concern to the indigenous companies and their business partners. One consequence is a lack of legitimacy attached to public decision making. The informants from foreign companies claimed that the Local Content Act and other governmental political decisions were made for the industry without the real industry participation; for example, one argued that when Local Content Act was developed, "our arguments and practical suggestions were not considered seriously". Another big indigenous company also corroborated; "political decisions are made top-down, by politicians isolated from business realities.

... Political interference and rate of changes in pertinent leadership positions are too frequent. The union informant also noted: "for example, there were five group managing directors for NNPC in about the last four years. The reasons behind shift in top positions are mainly political rather than strategic, which implies no room for continuity as every management team usually has new policies/agenda". (An indigenous service provider company informant).

The informants generally considered the governmental bodies as highly bureaucratic and thus, creating unnecessary delays, both in relation to certification and project approvals. One foreign company said, "... as part of a new and comprehensive supplier development program, one foreign company employed an unqualified but potential indigenous company as a sub-contractor to an offshore drilling project. The project never takes off due to bureaucracy in NAPIMS-NNPC-DPR". Another foreign company illustrated this using the Agbami Field Development Program which is delayed for six years for plan approval by the JV-NNPC. "Varied levels of bureaucratic interests are experienced at every committee due to special interests of board members" was expressed by another local informant.

\section{Relationship 6: Indigenous suppliers and other indigenous companies}

Both indigenous and foreign companies express a strong reluctance among local suppliers to collaborate and to enter strategic partnerships or merge into larger units.
This reluctance leads to at least two significant negative effects on the competitive power. Firstly, small companies are less capable of developing or accessing resources and competencies necessary to comply with buyer requirements. One local service provider expressed that:

"...the ruling attitude of local suppliers is that it is better with 5000 companies than 5000 shareholders. They think all or nothing. Indigenous companies are unwilling to collaborate and share resources with a company in the same line of business having spare capacity. We wanted to lease equipment not in use from a local company, but they refused, regardless of our financial offer". An indigenous service provider company informant, 08 October, 2010).

Secondly, the lack of consolidation implies that indigenous companies are too small for large integrated contracts or contracts which presuppose integrated delivery processes. One supplier summarized the collaborative environment as: "Nigerian companies lack trust in inter-company relationships, and fear losing full control, even when there is an obvious rationale for consolidation".

The findings thus far reveal constraints related to actor bonds, activity links and resource ties. A table summarising the three dimensions is provided in Appendix 3.

\section{DISCUSSION AND IMPLICATIONS}

Our data reveals at least three basic capabilities necessary for the indigenous company in order to increase local content in the Nigerian oil and gas industry. Firstly, the indigenous company needs capital for investments and lines of credit for their operations. Secondly, they need competence in terms of technological and managerial areas. This can be on different educational levels ranging for vocational schools to university level, and competence developed in $R$ and $D$ institutions more or less attached to the educational institutions. But capital and knowledge is not a sufficient condition for local industrial participation. The indigenous company will very often have a competitive disadvantage to other foreign suppliers. One reason is that the MNE's (that is, the foreign oil and gas operators in Nigeria) already have competitive a global suppliers involved, and it is reason to assume that a developing country supplier will, with exception of suppliers providing less advanced and low skilled deliveries, be considered inferior. A second reason is related to local content requirements, and thus acknowledging that the free market will discourage the indigenous company. We need a third capability which actually connects the indigenous company to the supply chain. This capability can be 
labelled delivery possibilities, and rest on the assumption that the indigenous company possesses the first two capabilities, namely capital and competence. In the following we will discuss these three capabilities and attach the relevant actors to the capabilities. By doing so, we see that the actors are interdependent in their contribution to local content.

Starting with the capital the banks and financial institutions are assumed to have significant problems in providing required capital at a reasonable interest rate for the indigenous company. This lack of funding can be related to a combination of reasons. There can be lack of professionalism in the banks leading to unrealistic risk assessments and very high risk premiums, or small scale disadvantages in the banking sector. But it could also be related to lack of public acknowledged systems to monitor past payback behaviour among the borrowers (industrial regulators) and weak legal protection for lender (legal system). Some of the banks indicated a general problem with the borrowers related to payback behaviour and professionalism when presenting business proposals, budgets and strategies. It is therefore possible that consolidation among indigenous companies, which are generally small in size, can improve professionalism and result in reduced perception of risk among the lenders. Finally, operating credit requirements are based on the assumption that the buyer pays weeks or months after deliveries. The question is to which the MNE's as buyers should voluntarily reduce the credit times, in order to lessen the local supplier's requirement for operating credit. From this, it can be argued that the provision for credit is contingent upon at least five more or less interdependent institutions; the banks, the authorities, the legal system, the foreign buyers and the indigenous company itself.

The indigenous suppliers need not only capital and equipment, but also technical and managerial competencies. Competence is a second capability required for the indigenous company. The educational institutions provide educated candidates to the industry which is a precondition for developing a sustainable industrial base. These can include all competence areas from skilled welders to petroleum engineers on university graduate level. Furthermore, the $R$ and $D$ institutions generate technological and managerial knowledge and facilitate innovation. Based on several informants the knowledge sector suffers from weak relationships to the industry and weak incentives from industrial regulators to facilitate tighter relationships between the "producer" and the "applier" of knowledge.

The foreign companies, of which the MNE play a dominant role, can with a basis in collaboration with knowledge and $R$ and $D$ institutions, enhance creation and diffusion of knowledge into indigenous companies and indirectly breed the ground for local content. It is well known from industrialized emerging oil and gas nations that the MNEs possess significant resources and abilities to transfer technology to indigenous universities. Necessary capabilities can also be accessed through supplier development programs where foreign operators connect indigenous suppliers through a learning process with established foreign suppliers. This willingness is, however, dependent on incentives from industrial regulators, and protection from legal system. Without a legal system protecting patent rights etc., technology transfer can hardly be justified. Finally, the indigenous company probably need to pass a lower threshold for being capable of apply advanced knowledge. Small scale businesses will always be constrained in long term investments in new applications and business operations. In all, again we see that required competence is an interaction between several actors in the industrial network. These include the educational and $R$ and $D$ institutions, foreign companies in the way they sustain technology transfer, the industrial regulators applying incentives and laws to sustain knowledge creation and industrial application, a functional legal system giving necessary protection and the knowledge demand from indigenous companies.

The delivery possibilities are crucial for industrial participation. One basic assumption for these possibilities is that the indigenous company possesses sufficient capital and relevant competence, which can be described as the raw materials necessary for industrial access. But without delivery possibilities, capital and competence is useless. This assumption is in support for the notion that "..no company can exploit its own resources except in relationships with other actors and their set of resources" (Ford et al., 2003). The foreign MNEs possess vast amounts of capital, technology and power, and control the oil and gas industry and most oil supply contracts to a large extent. Thus, they can make or unmake the successful participation of indigenous suppliers. How can a small local enterprise actually enter the bidding process, and successfully be awarded a contract? One piece of the answer is related to the structures of contracts and size of scope. Even though the size of contracts can be very large, complex and integrated in developed economies, the small scale businesses in developing countries should be taken into consideration when designing contract packages thus allowing smaller enterprises to qualify.

This again is dependent upon a recognized qualification and registration system within the responsibility of industrial regulators and/or National Oil Companies (NOC's). Some other types of improvements that can enhance the local content is initiating changes in duty regimes, favour local production compared to imports and give incentives to foreign companies that help to make indigenous suppliers internationally competitive.

The legal system is also crucial here and a weak legal system may easily jeopardize the ability to develop resource ties, activity links and actor bonds between 


\section{Finance Educat.\& Foreign Industrial Legal Infra- Indigen. institut. R\&D inst. comp. regulators system structure B2B}

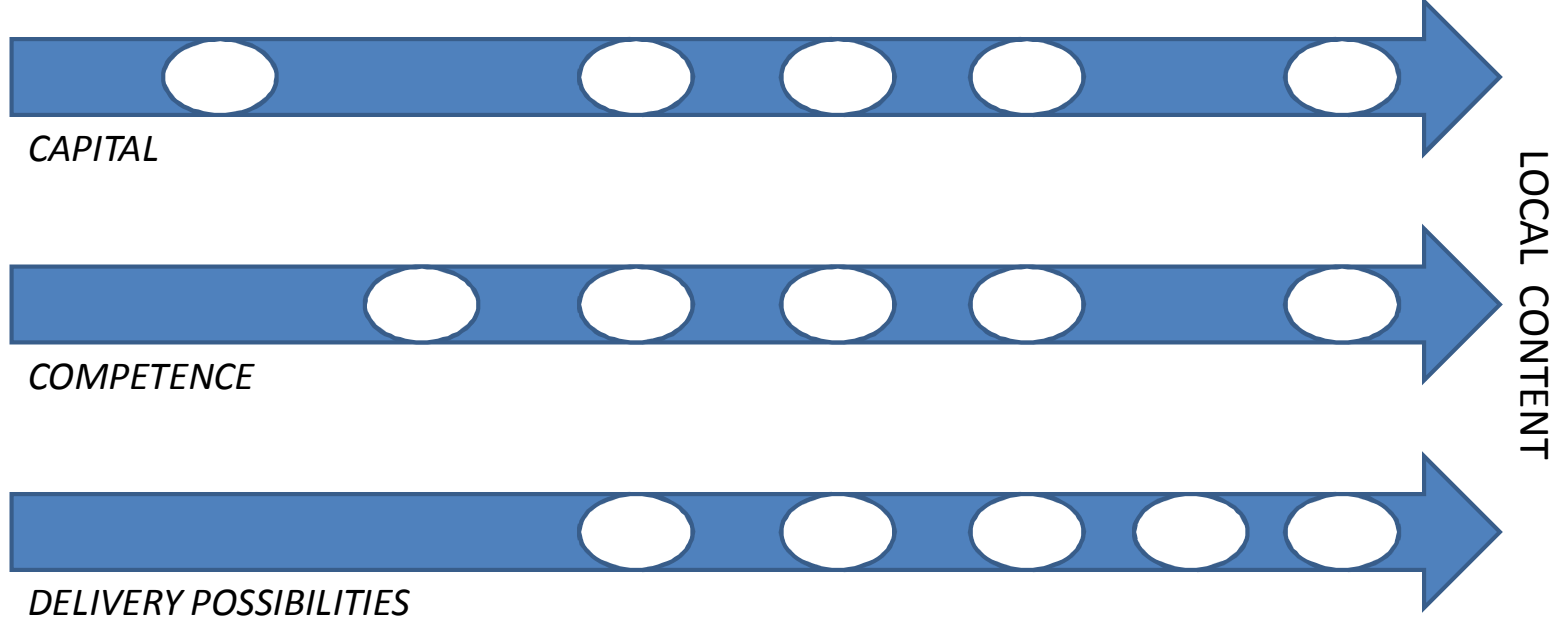

Figure 1. Core capabilities and providers enforcing local content.

indigenous suppliers and foreign operators. The legal system must be cleaned up in order to enable both foreign and indigenous companies to trust legal protection. The legal processes should be redesigned to suit the needs of business partners and individuals. A strong legal system is required to provide formal models of trust through formal contract and implementation mechanisms. The court system has to be trustworthy and adequately speedy without jeopardizing due process.

Furthermore, in developing countries, a large part of the private sector is family owned or partly informal soleproprietorships which make formal networking difficult. Therefore, policy should not only concentrate on passing good local content laws, but also to formalize business practice, establish management support programs and improve legal enforcement mechanisms. Infrastructure also represents a barrier to local content. Firstly, a dysfunctional infrastructure represents a cost disadvantage compared to foreign suppliers. The government must therefore, invest in the improvement of infrastructures such as pipelines and power supply, and thereby remove some of the most apparent barriers to local competitiveness.

A final aspect of importance to increase the delivery possibilities is related to internal and inter-organizational strategies. It is again about company size. Our interview data show that there is a serious problem of poor management and business strategy among indigenous companies. They are small, mostly informal and unable to compete in the modern economy. Globalization and opening up of African economies have actually worsened the competitive position of African companies as local production is in danger of being obliterated by cheaper and better quality imports. There is the need for indigenous business owners to modernize and employ trained managers who can compete in the new global economy. The actor bonds, resource ties and activity links between the foreign companies and indigenous suppliers need be strengthened. One very important means of achieving this is to strengthen the financial, managerial and technological robustness among indigenous companies through consolidation. The existing sizes of indigenous suppliers are generally small, and difficult to make competitive unless cooperative relationships between indigenous suppliers are significantly extended. Reluctance to enter intra-industrial collaboration and perception of completeness may thus, reduce foreign companies' willingness and ability to develop a Nigerian supplier market.

Summing up, the three core capabilities; capital, competence and delivery possibilities, are by no means the sole responsibility for one actor. Our discussion for far, indicates that several actors are necessary to build, secure and develop the capabilities leading to increased local content. Furthermore, the behaviour and pattern of actions among these actors are interdependent. This interdependency is illustrated in Figure 1.

The investigation of the six relationships confirms a breach of the myth of the company as complete, and that of independent. It can thus be argued that the ability of the country to facilitate a competitive indigenous supplier industry rests on the assumption that the individual company is incomplete and highly interdependent with actors in the industrial network. Our results correspond with the industrial network view that companies are interconnected in the industrial system for better or for worse 


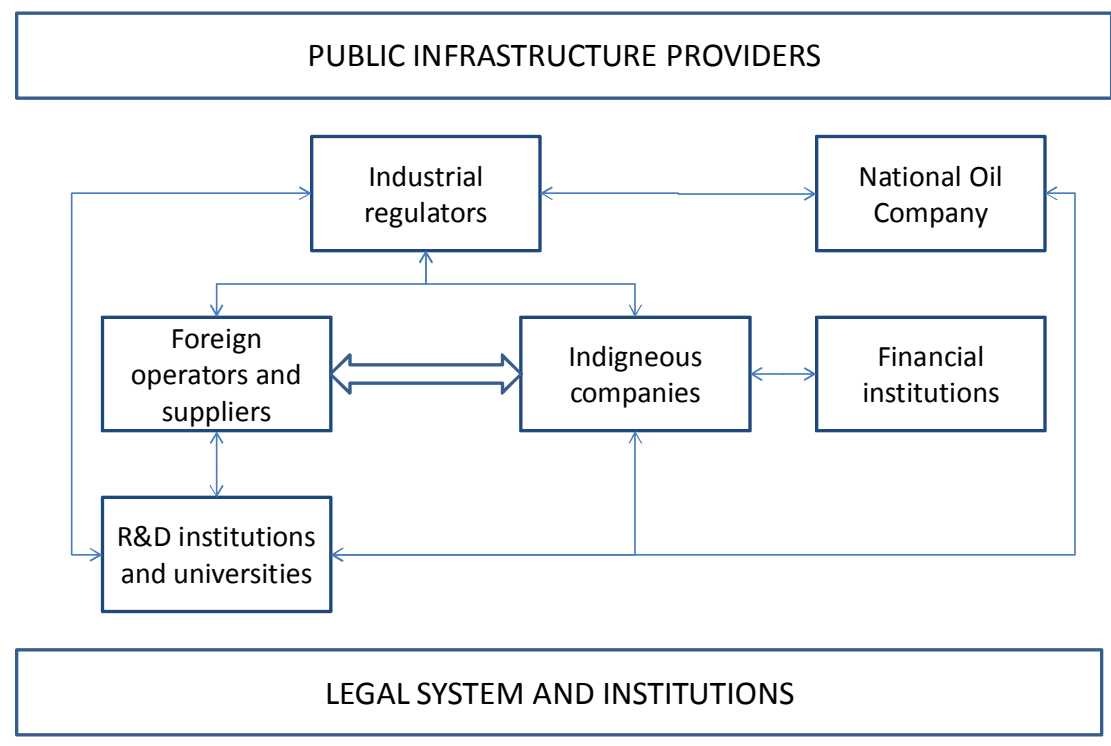

Figure 2. Crucial actors and relationships in the oil industrial network of Nigeria.

(Håkansson and Snehota, 1995; Ford et al., 2003). As Ford et al. (2003) put it; no company is complete or independent in relation to its industrial context. The importance of inter-connected boundaries and destinies is probably more pertinent in the case of natural resources extraction in developing countries because the national economy is very dependent on the resources.

The relationships in the industrial network illustrate that the actors do not individually possess or control resources necessary to develop the competitiveness of indigenous suppliers. This can be illustrated by the following example: The MNE has access to unlimited capabilities from the worldwide market, and capable of exploiting oil and gas resources without local suppliers. However, the Local Content Act imposes a constraint on them in that any foreign company ignoring local supplier implementation in the supply chain can be met with sanctions. Without taking actively part in developing the Nigerian industrial base, the future may be jeopardized. The initially complete foreign company has thus become incomplete, with increasing dependence on resource development and sharing with indigenous suppliers. This finding is in support of the notion by Ford et al. (2003) that no company can exploit its own resources except in relationships with other actors and their set of resources. A summary of the relationships between the actors and network in which the relationships are embedded in order to facilitate local content are illustrated in Figure 2.

Figure 2 illustrates the interdependencies among actors of the Nigerian oil and gas industry and support the notion that business interaction takes place between active actors in the surrounding network (Ford et al., 2003).

Managers of all companies and institutions involved in the oil industry supply network should understand the importance of networking to achieve increased participation of indigenous companies in oil industry supply contracts. In this sense, managers need to move away from a classical strategy of beating the competition and profiting at the expense of their purchasers and suppliers and rather work with them. It is important for each actor to understand the complexity of the market environment and the different actors who control different types of resources and provide different complementary resources.

The foreign companies are not the only actors of importance for achieving local content. On the other hand, these companies and in particular the MNEs are very powerful in the network and they need to realize their symbiotic relationships with the local economy and society. They need to move towards more responsible networking in the country by supporting the ideas behind the Local Content Act. The notion "no business is an island" (Håkansson and Snehota, 1989) applies even to large, powerful, global oil firms operating in developing countries like Nigeria. Our data show that easier tender contracts and procurement procedures as well as financial, technical, and managerial collaboration with indigenous companies, local research institutes and universities at the state and federal levels are required to achieve this aim. As indigenous companies benefit, they are likely to become positive advocates for the foreign oil companies.

\section{Conclusion}

The aim of our study was to explore the interrelatedness of public and industrial actors in pursuing larger participation of indigenous companies in the Nigerian oil 
and gas industry. Our point of departure is the importance of local supply content in ensuring development effects of extractive industries like oil and gas in developing countries, as well as the continued legitimacy of the foreign oil companies. Conceptually, we approached the research problem by using the industrial network perspective in which we examined the dimensions of industrial relationships among actors in the Nigerian industrial network.

The empirical basis for our study is based on 18 indepth interviews supplied with background information about the individual companies gathered from web sites. The supplementary material was primarily applied as a way to improve informant diversity. The informants varied with respect to representativeness from each institution, ranging from corporate specialists and -managers to CEOs. The sensitivity in revealing business philosophies and frustration towards governmental bodies and industrial actors also represent limitations. In a summary, however, we find the limitations acceptable for drawing our conclusions. We found out that formal networking is weak due to many problems: economic and social infrastructural inadequacies; weak legal infrastructure; weak financial sector; low level of trust among major actors in the industrial network due partly to the weak legal infrastructure; low level of support for local suppliers by foreign oil companies; absence (until recently) of a local content law that encourages and even forces the major actors to consider local companies in supply contracts; low level of support for local industry by the government; weak managerial competences of local companies; low level of indigenous $R$ and $D$ and weak links between local universities, research institutions and companies. However, the new local content law is one factor that can improve local content in the medium term.

Based on these findings, we have suggested a conceptual model to encapsulate the processes and structures required of all the parties to achieve sustainable local supply content in extractive industries in developing countries like Nigeria. Our conceptual model shows the links and ties between the range of actors and their interconnections with the socio-political context that regulates and enables natural resource extraction in developing countries. The findings are also relevant for other developing countries in which a growing awareness of the importance of achieving local content is prevalent.

Further research could test the normative conceptual model more empirically, preferably on other developing oil and gas nations. This will provide a more understanding of the interplay between crucial actors in the oil industrial network. A second research avenue could investigate how Local Content Acts affect the competitiveness of local supplier industry.

\section{ACKNOWLEDGEMENTS}

The research is financially supported by the Epci
Foundation and Shell Norway.

\section{REFERENCES}

Adams M, Osho G, Coleman Q (2008). The politics and political implications of oil and gas exploration in Africa: An analysis of American oil corporations in Nigeria. Int. Bus. Econ. Res. J., 12: 107116.

Anderson E, Weitz B (1989). Determinants of continuity in conventional industrial channel dyads. Mark. Sci., 8(Fall): 310-323.

Aharonson BS, Baum JA, Feldman MP (2007). Desperately seeking spillovers? Increasing returns, industrial organization, and the location of new entrants in geographic and technological space. Ind. Corp. Change, 16: 89-130.

Blau PM (1964). Exchange and Power in Social Life. New York: Wiley.

Blois KJ (1997). When is a relationship "a relationship? In Relationships and Networks in International Markets by Gemünden HG, Ritter T, Walter A. (eds). Oxford: Elsevier.

Boscheck R (2007). The governance of oil supply: an institutional perspective on NOC control and the questions it poses. Int. J. Energy Sect. Manage., 1(4): 366-389.

Ford D, Gadde L-E, Håkansson H, Snehota I (2003). Managing Business Relationships. Chichester: Wiley.

Ford D, Gadde L-E, Håkansson H, Snehota I (2006). The Business Marketing Course. Managing in Complex Networks, Chichester: Wiley.

Frynas JG, Paulo M (2007). A new scramble for African oil? Historical, political, and business perspectives. Afr. Aff., 106/423: 229-251.

Giroud A (2007). MNEs vertical linkages: The experience of Vietnam after Malaysia. Int. Bus. Rev., 16: 159-176.

Hansen MW, Pedersen T, Petersen B. (2009). MNC strategies and linkage effects in developing countries. J. World Bus., 44: 121-130.

Håkansson H, Snehota I (1989). No Business is an Island: The Network Concept of Business Strategy. Scand. J. Manage., 3(3): 187-200.

Håkansson H, Snehota I (1995). Developing Relationships in Business Networks. London: Routledge.

Ivarsson I, Alvstam CG (2009). Learning from foreign TNCs: a study of technological upgrading by local suppliers to $A B$ Volvo in Asia and Latin America. Int. J. Technol. Manage., 48(1): 56-76

Jensen J, Tarr D (2008). Impact of local content restrictions and barriers against Foreign Direct Investment in services. The case of Kazakhstan's accession to the World Trade Organization. Eastern Eur. Econ., 46(5): 5-26.

Johannisson B, Ramirez-Pastillas M (2002). The institutional embeddedness of local inter-firm networks: A leverage for business creation. Enterp. Reg. Dev., 14: 297-315.

Kalafatis SP, Miller H (1997). A Re-examination of the CommitmentTrust Theory. In Relationships and Networks in International Markets. Gemünden HG, Ritter T, Walter A (eds), Oxford: Elsevier.

Kwon CW, Chun BG (2009). Local Content Requirement under Vertical Technology Diffusion. Rev. Dev. Econ., 13(1): 111-124.

Lahiri S, Ono Y (1998). Foreign direct investment, local content requirement, and profit taxation. Econ. J., 108: 444-457.

Local Content Act (2010). Nigerian Oil and Gas Industry Content Development Bill 2010. Explanatory Memorandum. The Nigerian House of Representative March $3^{\text {rd }} 2010$.

Nwosu HU, Nwachukwu IN, Ogaji SOT, Probert SD (2006). Local involvement in harnessing crude oil and natural gas in Nigeria. Appl. Energy, 83: 1274-1287.

Pursell G (2001). The Australian experience with local content programs in the auto industry - Some lessons for India and other developing countries. J. World Trade. 35(2): 379-393.

Qui LD, Tao ZG (2001). Export, foreign direct investment, and local content requirements. J. Dev. Econ., 66(1): 101-125.

Silvestre BdS, Dalcol PRT (2009). Geographical proximity and innovation: Evidences from the Campos basin oil and gas industrial agglomeration-Brazil. Technovation, 29: 546-561.

Tallman S, Phene A (2007). Leveraging knowledge across geographic boundaries . Org. Sci., 18(2): 252-260.

Takechi K, Kiyono K (2003). Local content protection: Specific-factor model for intermediate goods production and market segmentation. 
Jpn. World Econ., 15(1): 69-87.

Tourangeau R, Rips LJ, Rasinski K (2000). The Psychology of Survey Response. Cambridge: Cambridge University Press.

Veloso FM (2006). Understanding local content decisions: Economic analysis and an application to the automotive industry. J. Reg. Sci., 46(4): 747-772.
Zerbe WJ, Paulhus DL (1987). Socially desirable responding in organizational behavior. A reconception, Acad. Manage. Rev., 12:250-264.

WTO

www.wto.org/english/thewto_e/...e/local_content_measure_e.htm Downloaded January 7 th 2011 . 


\section{APPENDIX 1}

Interview guide

(i) Provide a brief on your company profile including its mandates, ownership, business interests and recent activities in the Oil and Gas industry.

(ii) Describe access to finance and fiscal issues by (a) your company (b) other companies of the same business interest; and (c) indigenous companies (d) foreign multinationals in the Nigeria O\&G industry;

If there is limited access, Why?

How could this be mitigated?

What chances are for merger and integration to access wider markets?

(iii) Discuss the aspects of (a) managerial Skills, (b) facility Skills and (c) company competencies that affect the operations of the companies with similar stakes to yours in the industry in Nigeria

(iv) To what extent is Global Sourcing supporting the competitiveness of indigenous versus foreign companies in the industry?

(v) Is home country loyalty a counteracting or supporting factor to the competitiveness of indigenous companies in the country? Discuss. (vi) Describe any differentials you have observed in the business philosophy of the companies in your areas of competence versus others.

(vii) What is your idea of the Nigerian Factor? How do these affect businesses in the Oil and Gas sector?

(viii) To what extent have public infrastructures supported the operations of indigenous and foreign Oil and Gas companies in Nigeria?

(ix) Had your company ever been in court on issues bordering on contacts and/or litigation? If yes, provide an insight.

(x) How would you describe the Nigeria legal system as a factor for supporting Local Content?

(xi) Describe generally the individual CSR of the indigenous versus the foreign multinationals.

(xii) What level of collaboration exist between your company and indigenous companies?

(xiii) Discuss the bonds between your company and the foreign counterparts.

(xiv) What kinds of relationships exist between your company and the Nigerian Universities/R\&D institutions?

(xv) Discuss the specific areas that the collaborations above can improve (a) capacity building (b) research and training and (c) technological transfer and (d) overseas opportunities within the industry? 


\section{APPENDIX 2}

The persons interviewed directly and their nature of businesses

\begin{tabular}{lll}
\hline Position & Origin & Type of business \\
\hline (1) Vice president and (2) head of procurement & Foreign & Oil and gas exploration, and production \\
Manager, local content & Foreign & Oil and gas exploration, and production \\
Principal partner & Indigenous & Service provider \\
(1) Head public sector and (2) legal adviser & Indigenous & Finance institution \\
Managing director & Indigenous & Consulting \\
Senior assistant general secretary & Indigenous & Labour union \\
Oil and gas exploration, and production & Indigenous \\
Head of marketing & Indigenous & Catering \\
(1) Managing director and (2) manager & Indigenous Service provider \\
Managing director & Indigenous Service provider \\
Deputy manager, local content & Indigenous & Oil and gas exploration, and production \\
Deputy managing director & Indigenous Industry supplier \\
(1) Business school dean and (2) postgraduate school dean & Indigenous & University \\
Local content analyst & Indigenous Government/regulatory \\
\hline
\end{tabular}

\section{APPENDIX 3}

A summary of relationship dimensions between actors in the Nigerian oil and gas industry network.

\begin{tabular}{|c|c|c|c|c|c|}
\hline Relationship & & \multicolumn{2}{|l|}{ Actor bonds } & Activity links & \multirow{2}{*}{$\begin{array}{l}\text { Resource ties } \\
\text { Poor risk assessment by bank. }\end{array}$} \\
\hline \multirow{3}{*}{$\begin{array}{l}\text { 1. IS and } \\
\text { institutions }\end{array}$} & \multirow{3}{*}{ finance } & $\begin{array}{l}\text { Fear of } \\
\text { behaviour. }\end{array}$ & payback & $\begin{array}{l}\text { Lack of consultation on } \\
\text { business plans. }\end{array}$ & \\
\hline & & $\begin{array}{l}\text { Low international } \\
\text { legitimacy. }\end{array}$ & funding & $\begin{array}{l}\text { Lack of bank insight into IS } \\
\text { business processes and } \\
\text { performance. }\end{array}$ & $\begin{array}{l}\text { Poor IS business plans and } \\
\text { analyses. }\end{array}$ \\
\hline & & \multicolumn{3}{|c|}{ Lack of trust in legal system. } & $\begin{array}{l}\text { i) Lack of bank resource } \\
\text { consolidation. } \\
\text { ii) Lack of governmental. banking } \\
\text { leverage and capital. }\end{array}$ \\
\hline
\end{tabular}

\begin{tabular}{|c|c|c|c|}
\hline \multirow{3}{*}{$\begin{array}{l}\text { 2. } R \text { and } D \text { institutions/ } \\
\text { universities and industry }\end{array}$} & Industry fear of disclosing info. & $\begin{array}{l}\text { Lack of joint or cooperative } \\
\text { activities in research and } \\
\text { education. }\end{array}$ & $\begin{array}{l}\text { Weak sharing and investment in } \\
R \& D \text { and competence building. }\end{array}$ \\
\hline & Lack of industrial commitment. & $\begin{array}{l}\text { Weak } \\
\text { connection. }\end{array}$ & $\begin{array}{l}\text { IS depends on tech transfer from } \\
\text { foreign companies. }\end{array}$ \\
\hline & $\begin{array}{l}\text { Industry questioning university } \\
\text { integrity and reputation. }\end{array}$ & & Weak equipment sharing. \\
\hline \multirow{3}{*}{$\begin{array}{l}\text { 3. IS and } \\
\text { foreign companies }\end{array}$} & Fear of IS corruption. & $\begin{array}{l}\text { Lack of advanced activity } \\
\text { adaptations. }\end{array}$ & $\begin{array}{l}\text { O\&G awareness of lack of IS } \\
\text { competence and skills. }\end{array}$ \\
\hline & $\begin{array}{l}\text { Fear of IS incompetence and } \\
\text { inefficiencies. }\end{array}$ & $\begin{array}{l}\text { Awareness of LC Supplier } \\
\text { Development Programs. }\end{array}$ & $\begin{array}{l}\text { IS lack of operational and } \\
\text { investment capital. }\end{array}$ \\
\hline & $\begin{array}{l}\text { IS fear of foreign companies } \\
\text { favouring home country } \\
\text { suppliers. }\end{array}$ & $\begin{array}{l}\text { IS limited by large integrated } \\
\text { contracts. }\end{array}$ & Dysfunctional infrastructure. \\
\hline $\begin{array}{l}\text { 4. The legal system and } \\
\text { the industrial network }\end{array}$ & $\begin{array}{l}\text { Low trust in legal system and } \\
\text { lack of independence. }\end{array}$ & $\begin{array}{l}\text { Delays in enforcement and } \\
\text { court decisions. }\end{array}$ & $\begin{array}{l}\text { A malfunctioning legal system } \\
\text { constraints resource development } \\
\text { and sharing. }\end{array}$ \\
\hline
\end{tabular}


Fear of LC incompatibility.

5. Regulatory bodies and foreign companies and $R \& D /$ Universities.

Low mutual trust in decision processes.

Lack of commitment beyond general university funding.
Weak joint O\&G - regulatory Implementation of LC Act and body initiatives. public-O\&G boards.

O\&G perceptions of delays Custom/duty regime favours import and endless bureaucracy.

Lack of activities and

incentives promoting $\mathrm{O}$ and $\mathrm{G}$ industry and $\mathrm{R}$ and $\mathrm{D} /$ University connection.
6. IS and other Low intra-IS trust. indigenous companies
Low activity collaboration.

Fear of external control.
Weak resource bundling. Weak business philosophy.

IS = INDIGENOUS Supplier; O\&G= Oil and Gas Industry, JV = Joint Ventures, LC = Local Content. 